To cite this article: Zeyneloglu HB, Tohma YA, Onalan G, Gunakan E. Evaluation of the uterine cavity and fallopian tubes in one step in patients undergoing assisted reproductive technology treatment: hysterosalpingo-foam sonography (hyfosy) in combination with hysteroscopy. Turk J Womens Health Neanatol 2021; 3(2): 27-32

- Original Article

\title{
Evaluation of the uterine cavity and fallopian tubes in one step in patients undergoing assisted reproductive technology treatment: Hysterosalpingo- foam sonography (hyfosy) in combination with hysteroscopy
}

\section{Yardımc üreme teknolojileri tedavisi uygulanacak hastalarda uterin kavitenin ve fallop tüplerinin tek adımda değerlendirilmesi: Histeroskopi ile birlikte histerosalpingo-köpük sonografi (hyfosy)}

Hulusi Bulent Zeyneloglu*1 $\square$, Yusuf Aytac Tohma ${ }^{1} \square$, Gogsen Onalan ${ }^{1} \square$, Emre Gunakan²$\square$

${ }^{1}$ Department of Obstetrics and Gynecology, Division of Reproductive Endocrinology and Infertility, Faculty of Medicine, Baskent University, Ankara, Turkey

${ }^{2}$ Department of Obstetrics and Gynecology, Faculty of Medicine, Baskent University, Ankara, Turkey

\begin{abstract}
Aim: To report on the utilization of hysterosalpingo-foam sonography (HyFoSy) with hysteroscopic evaluation for selected patients undergoing Assisted Reproductive Technology Treatment (ART), whereby we aimed to assess the effectiveness of HyFoSy before hysteroscopy.

Material and Method: This retrospective study included 36 infertile women referred to Baskent University's Ankara Hospital Infertility Clinic in 2017-2019. HyFoSy was applied with hysteroscopy in one step for patients who had not previously been evaluated for tubal patency or who had to be re-evaluated.

Results: Two patients were diagnosed with tubal obstruction by HyFoSy and were treated with hysteroscopic tubal catheterization, and tubal patency was obtained after this procedure. HyFoSy was applied in seven patients (19.49\%) because their previous hysterosalpingography (HSG) reports were doubtful. Although previous HSG had shown tubal obstruction in three patients, the standard passage of the foam from the fallopian tubes to the abdominal cavity was observed when HyFoSy was applied.

Conclusion: The one-step method that we apply in our clinic seems appropriate for both patients and clinicians because it speeds up the evaluation steps of the uterine cavity and fallopian tubes before the next ART attempt.

Keywords: Hysteroscopy; infertility; hysterosalpingo-foam sonography; hystero-contrastsonography
\end{abstract}

Corresponding Author*: Hulusi Bulent Zeyneloglu, Sehit Temel Kuguluoğlu Sok. No 32, Bahcelievler, Ankara, 06490 Turkey

E-mail: hulusi.zeyneloglu@gmail.com

Doi: 10.46969/ezh.940157

ORCID: 0000-0002-0289-2642

Geliş tarihi: 20.05 .2021

Kabul tarihi: 16.06.2021 


\section{Öz}

Amaç: Biz bu çalışmada, yardımcı üreme teknolojileri tedavisi uygulanacak seçilmiş hastalarda tedavi öncesinde aynı seansta uygulanan histeroskopi ve histerosalpingo-köpük sonografinin etkinliğini değerlendirmeyi amaçladık.

Gereç ve Yöntem: Bu retrospektif çalışma, 2017-2019 yılları arasında Başkent Üniversitesi Ankara Hastanesi İnfertilite Kliniği'ne başvuran 36 infertil kadını içermektedir. Merkezimizde, daha önce tubal açıklığı açısından değerlendirilmemiş veya yeniden değerlendirilmesi gereken hastalar için bir adımda histeroskopi ile HyFoSy uygulanmaktadır ve çalışmaya bu hastalar dahil edilmiştir.

Bulgular: Iki hastaya HyFoSy ile tubal obstrüksiyon tanısı konuldu ve histeroskopik tubal kateterizasyon ile tedavi edildi ve bu işlemden sonra tubal açıklık elde edildi. Önceki histerosalpingografi (HSG) raporları şüpheli olduğu için 7 hastaya $(\% 19,49)$ HyFoSy uygulandı. Üç hastada, önceki HSG incelemesinde tubal obstrüksiyon görülmesine rağmen, HyFoSy uygulandığında köpüğün fallop tüplerinden karın boşluğuna normal geçişi gözlendi.

Sonuç: Kliniğimizde uyguladığımız bu tek adımlı yöntem hem hastalar hem de klinisyenler için uygun görünmektedir, çünkü uygulanan yöntem bir sonraki ART girişiminden önce uterin kavitenin ve fallop tüplerinin değerlendirme adımlarını hızlandırmaktadır.

Anahtar kelimeler: Histeroskopi; infertilite; histerosalpingo-köpük sonografi, histerokontrast sonografi

\section{Introduction}

In vitro fertilization/intracytoplasmic sperm injection (ICSI) procedure is an expensive treatment method for infertility and its psychologic and time burden to the couple. Therefore, a thorough evaluation must be performed beforehand, and it must be offered according to the guidelines' recommendations. Tubal and uterine evaluation is a must for every patient who undergoes IVF/ICSI treatment for the risk of having hydrosalpinx (1) or uterine abnormalities (2), which decreases the chances of live birth. Conventional hysterosalpingography (HSG) is the standard method to evaluate the tubes and the contour of the uterus. However, it requires X-ray exposure and exact timing, along with the transfer of the patient to the radiology department (3). It may also cause mild to severe pain and possible allergic reactions to the contrast medium, in addition to patients' reluctance due to the fear of pain as perceived from social media (3). Although HSG and the laparoscopic dye test are the most recognized tests to evaluate fallopian tube patency, many more recent modalities have been introduced, such as hydro-laparoscopy (4) and hysterosalpingo-contrast sonography (HyCoSy), which is comparable to HSG $(5,6)$. Hysterosalpingofoam sonography (HyFosy) is a relatively new approach that uses an ultrasonographic contrast gel medium to visualize the fallopian tubes (7). It is superior to sonohysterosalpingography with saline (8), and its comfort was proven in earlier studies $(9,10)$.

In addition to fallopian tube evaluation, every patient undergoing IVF/ICSI treatment must have their endometrial cavity evaluated by transvaginal ultrasonography (TVUS), three-dimensional (3D) TVUS or HSG. The first step in the evaluation of the endometrial cavity is performed with TVUS and HSG. If an abnormality is detected in these procedures or if the patient is diagnosed with recurrent implantation failure, an office hysteroscopy may be performed as the second step of the evaluation. Hysteroscopy is superior to TVUS and HSG as it is effective in treatments besides diagnosing abnormalities in IVF patients $(11,12)$.

In our clinic, we utilize HyFoSy with hysteroscopy to evaluate IVF patients' tubal patency and endometrial cavity in one step. In this retrospective case series, we report this utilization of HyFoSy with hysteroscopic evaluation for IVF patients, and we aim to assess the effectiveness of HyFoSy before hysteroscopy.

\section{Material and Method}

This study was a retrospective case series that included 36 infertile women referred to Baskent University Ankara Hospital Infertility Clinic between 2017 - 2019. The study was approved by the Institutional Review Board of Baskent University and was performed following the ethical standards of the 1964 Declaration of Helsinki. Informed written consent was obtained from all patients before the procedure. Patients with risk factors of pelvic inflammatory disease, cervical dysplasia or cancer, and active uterine bleeding were excluded from the study, as were those who declined to participate.

Baseline TVUS was performed for all patients for a complete evaluation of the uterus, ovaries, and pelvic region on days 2-3 and 9-14 of the menstrual cycle. In case of suspicion of an endometrial abnormality resulting from TVUS or if the patient had recurrent implantation failure, office hysteroscopy was performed during days 9-14 of the menstrual cycle. In this group of patients, HyFoSy was applied with hysteroscopy in one step 
for patients who had not been previously evaluated for tubal patency or who had to be re-evaluated. The one-step procedure was performed between days 9-14 of the menstrual cycle to evaluate the development of the endometrium to predict implantation. HyFoSy was carried out under TVUS guidance just before hysteroscopy in the operating theatre of the IVF clinic. In some cases, the remaining HyFoSy solution was administered after the hysteroscopy to observe the patency if either of the tubes was initially observed to be occluded.

HyFoSy was performed according to previously reported product instructions $[8,13]$. During this procedure, approximately $10 \mathrm{~cm}^{3}$ of foam is introduced, through a cervical catheter, into the uterine cavity. This foam was created after mixing $5 \mathrm{mLExEm}$-gel ${ }^{\circledR}$ (containing hydroxyethyl cellulose and glycerol, IQ Medical Ventures BV, Delft, The Netherlands) with $5 \mathrm{~mL}$ of distilled water in a $10 \mathrm{~mL}$ syringe.

All patients were awake and cooperative during HyFoSy and were shown the status of their tubal patency; however, they were then given mild sedatives before the office hysteroscopy. HyFoSy was performed before the office hysteroscopy because procedures performed during hysteroscopy may cause bleeding and tissue removal, entering the peritoneal cavity through the fallopian tubes. Mild sedation was performed with the intravenous administration of midazolam $(0.1 \mathrm{mg} / \mathrm{kg})$ and fentanyl (1-2 $\mu \mathrm{g} / \mathrm{kg}$ ). All patients were advised to use barrier methods to avoid accidental pregnancy and possible infection exacerbated by the deposition of semen in the vagina. All patients were given $100 \mathrm{mg}$ of doxycycline (Tetradox, Teva Turkey, Istanbul, Turkey) twice a day for five days. Office hysteroscopy was performed using the Bettochi Integrated Office Hysteroscope (0.4 mm) (KARL STORZ SE \& Co., Tuttlingen, Germany). The same surgeon (HBZ) performed all procedures.

Clinical information, including the patient's age, aetiology of infertility, indications of hysteroscopy and HyFoSy, hysteroscopic findings, HyFoSy results, and previous HSG results, were extracted from medical records.

The data were analyzed by SPSS Statistics 25 for Windows (IBM Corp., Armonk, NY, USA). Continuous variables were presented as mean (range), and categorical variables as numbers and percentages.

\section{Results}

All patients were successfully evaluated with hysteroscopy and HyFoSy. The mean age of the patients was $35.8 \pm 4.2$ (27-45) years. Sixteen patients (45\%) had a previous IVF history (cycle numbers varied from 1 to 7$)$.

Etiologic factors for infertility are shown in Table 1. When the causes of infertility were considered, the most common cause was unexplained infertility $(52.8 \%)$, while the second was poor ovarian reserve $(16.7 \%)$.

\begin{tabular}{|l|c|}
\hline \multicolumn{2}{|l|}{ Table 1. Etiology for infertility } \\
\hline Factors & $\mathrm{n}(\%)$ \\
\hline Unexplained & $19(52.8)$ \\
\hline Male & $3(8.3)$ \\
\hline Tubal & $1(2.8)$ \\
\hline Poor ovarian reserve & $6(16.7)$ \\
\hline Endometriosis & $2(5.6)$ \\
\hline Anovulatory & $5(13.9)$ \\
\hline
\end{tabular}

Indications for hysteroscopy and HyFoSy were shown in Tables 2 and 3. Ten patients (27.7\%) underwent hysteroscopy due to repeated implantation failure, while eight (22.2\%) underwent hysteroscopy due to endometrial polyps. Two patients were diagnosed with proximal tubal obstruction by HyFoSy and treated with hysteroscopic tubal catheterization, and tubal patency was obtained after this procedure. HyFoSy was applied for seven patients (19.49\%) because their previous HSG reports were doubtful. HyFoSy was administered to one patient due to fear of pain.

\begin{tabular}{|l|c|}
\hline Table 2. Indications for hysteroscopy & $\mathbf{n}(\%)$ \\
\hline Indication & $10(27.7)$ \\
\hline Recurrent implantation failure & $8(22.2)$ \\
\hline Endometrial polyp & $4(11.1)$ \\
\hline Abnormal endometrial appearance on ultrasonography & $1(2.8)$ \\
\hline History of Asherman syndrome & $7(19.4)$ \\
\hline Previous uterine cavity surgery & $1(2.8)$ \\
\hline Elective & $2(2.8)$ \\
\hline Tubal catheterization & $1(2.8)$ \\
\hline Isthmocele management & $1(2.8)$ \\
\hline T-shaped uterus correction & $1(2.8)$ \\
\hline Subseptus resection & \\
\hline
\end{tabular}

Table 3. Indications for HyFoSy

\begin{tabular}{|l|c|}
\hline Indication & $\mathbf{n}(\%)$ \\
\hline Surgical intervention after HSG & $4(11.1)$ \\
\hline Doubtful HSG & $7(19.49)$ \\
\hline No previous HSG & $15(41.6)$ \\
\hline Fear of pain & $1(2.8)$ \\
\hline Shortness of time before IVF & $1(2.8)$ \\
\hline Control HSG after PID & $2(5.6)$ \\
\hline Very old HSG & $2(5.6)$ \\
\hline
\end{tabular}

HyFoSy: Hysterosalpingo foam sonography; HSG: Hysterosalpingography; IVF: In Vitro Fertilization

The results of HSG and HyFoSy are shown in Table 4. Although the previous HSG had shown tubal obstruction in three patients, the standard passage of the foam from the fallopian tubes to the abdominal cavity was observed when HyFoSy was applied. 


\begin{tabular}{|l|c|c|c|c|c|}
\hline Table 4. Results of HSG and HyFoSy & $\begin{array}{c}\text { Normal } \\
\text { HyFoSy }\end{array}$ & $\begin{array}{c}\text { Bilateral tubal } \\
\text { occlusion }\end{array}$ & $\begin{array}{c}\text { Unilateral tubal } \\
\text { occlusion }\end{array}$ & $\begin{array}{c}\text { Unilateral passage } \\
\text { with difficulty }\end{array}$ & $\begin{array}{c}\text { Bilateral passage } \\
\text { with difficulty }\end{array}$ \\
\hline No previous HSG & 18 & - & 3 & 2 & - \\
\hline Normal previous HSG & 2 & - & - & 2 & 2 \\
\hline Hydrosalpinx at HSG & - & - & 1 & - & - \\
\hline Occlusion at HSG & 3 & 1 & 1 & - & - \\
\hline T-shaped uterus with normal tubes & 1 & - & - & - \\
\hline HyFoSy: Hysterosalpingo foam sonography; HSG: Hysterosalpingography &
\end{tabular}

There were no early or late complications after HyFoSy before hysteroscopy. When the patients were asked whether they felt pain during or after the HyFoSy, they did not state any.

\section{Discussion}

This study aimed to investigate the effectiveness of HyFoSy before hysteroscopy in infertile patients prepared for assisted reproductive technologies treatment, and we showed that HyFoSy in combination with hysteroscopy might be used for rapid evaluation of the uterine cavity and fallopian tubes in patients who have not undergone HSG without no delay in planning further assisted reproductive technology treatments.

The appropriate evaluation of an IVF patient is the utmost important step before starting a treatment cycle. Usually, the patient's history, previous evaluations by HSG and hysteroscopy, and timely ultrasonographic examinations exclude most abnormalities. Two main studies, TROPHY (14) and inSIGHT (15), did not find a benefit of office hysteroscopy in IVF patients if previous ultrasonographic examination did not reveal any abnormalities. However, the weakness of these studies lies in the fact that biopsies were not performed to rule out endometritis. Endometritis can be diagnosed by the microscopic detection of pathologic plasma cells or endometrial stromal inflammation (16). A recent meta-analysis showed the benefit of hysteroscopy, especially in Asian patients (17). In addition, the presence of hydrosalpinx decreasing the likelihood of pregnancy must never be ignored (1). Patients with repeated implantation failure must be evaluated with meticulous care, re-examining earlier reports and sometimes repeating tests, including HSG and office hysteroscopy. In addition, these tests must be carried out quickly and in a single step, if possible, concerning the patient's already disturbed psychological state. Therefore, in our centre, we apply HyFoSy with hysteroscopy to evaluate infertile patients' tubal patency and endometrial cavity in one step, and in this study, we report the effectiveness of HyFoSy before hysteroscopy. This study has proven that HyFoSy combined with hysteroscopy is feasible for evaluating tubal patency and the uterine cavity consecutively in the same setting. Therefore, we speculated that this one-step method could be used to shorten the process of starting treatment in a group of infertile patients who want to achieve results quickly.

A recent study reporting the assessment of tubal patency through infusing air into saline during flexible office hysteroscopy (18) showed that $92 \%$ of patients preferred it when compared to previous HSG experiences. However, flexible hysteroscopy is used in this method, which is not preferred in many clinics because of its short endurance and limited surgical capabilities. In addition, high pressure may cause spasms, and tubal spasms with high pressure have been associated with lower pregnancy rates (19). Another approach is selective tubal chromopertubation, with considerable sensitivity (86\%) and specificity (88\%) (20). The advantage of this procedure over other tubal patency tests is that the dye is directly injected into the fallopian tube with hysteroscopic guidance. However, this procedure has some limitations; it does not offer direct visualization of the tubes, and in some cases, it may cause vasovagal syncope and pain. Another method is to observe fluid accumulation in the pouch of Douglas, but this only rules out the bilateral obstruction and does not define unilateral tubal patency (21).

In our setting, we perform HyFoSy before hysteroscopy because our experience has shown less pain for patients, and it allows them to adapt to office hysteroscopy more easily. In addition, there are few spasms because there is no high pressure or volume of the fluid forced into the tubal ostia. However, in the case of any trauma to the endometrial lining during hysteroscopic entry and biopsy, if required, bleeding may occur, and blood clots may be forced into the ostia afterwards.

The term "one-stop fertility clinic" was suggested in 2002, based on the results of office hydro-laparoscopy (22). It combines laparoscopy with hysteroscopy, demonstrating the status of tubal patency. However, it was concluded that it could not be applied for every woman since hydro-laparoscopy failed in up to $18 \%$ of patients (23). Therefore, in patients for whom tubal patency must be demonstrated, the combination of hysteroscopy with transvaginal sonographic observation 
has proven successful results with a sensitivity of $94 \%$ and a specificity of $94 \%$ (21). In addition, a one-stop fertility clinic approach using advanced ultrasonographic assessment has been reported; however, this method is not sufficient for the evaluation of patients before IVF (24).

Our study had some limitations, including its retrospective nature, the small number of cases, and the lack of a control group. Despite these limitations, in this study, we shared our case experience evaluating the uterine cavity and fallopian tubes in one step before starting an IVF procedure, and this method seems tolerable and feasible. In addition, this combination provides an acceptable offer to selected patients avoiding multiple tests which would take at least two months and possible delays in the treatment. However, the feasibility of this one-step method should be investigated further with well-designed large-scale prospective randomized controlled studies. Another limitation of our study was that we did not use any pain scales to assess patients' pain after the procedure.

In conclusion, patients in infertility clinics want to achieve results quickly and painlessly, with the minimal examination. Therefore, evaluations in the IVF/ICSI patient group must be performed with the fewest possible and most comfortable steps for both the patient and the clinician. For this reason, the one-step method that we apply in our clinic seems to be appropriate for both patients and clinicians because it does not require analgesia and anaesthesia, and it can be done in an outpatient setting for the evaluation of the uterine cavity and fallopian tubes.

\section{Declaration of Interest}

The authors report no conflict of interest.

\section{Funding}

None

\section{References}

1. Zeyneloglu, H.B., A. Arici, and D.L. Olive, Adverse effects of hydrosalpinx on pregnancy rates after in vitro fertilization-embryo transfer. Fertil Steril 1998; 70:492-499.

2. Bosteels J, van Wessel S, Weyers S, et al., Hysteroscopy for treating subfertility associated with suspected major uterine cavity abnormalities. Cochrane Database Syst Rev 2018; 12:CD009461.

3. HandelzaltsJE, LevyS, PeledY, etal., Informationseeking and perceptions of anxiety and pain among women undergoing hysterosalpingography. Eur J Obstet Gynecol Reprod Biol 2016; 202:41-44.

4. Suzuki, T, Shibahara $H$, Hirano $Y$, et al., Feasibility and clinical significance of endoluminal assessment by transvaginal salpingoscopy during transvaginal hydrolaparoscopy in infertile women. J Minim Invasive Gynecol 2005; 12:420-425.
5. Volpi E, De Grandis T, Zuccaro G, Patriarca A, Sismondi P. A new technique to test tubal patency under transvaginal sonographic control. Acta Obstet Gynecol Scand 1994; 73:797-801.

6. Maheux-Lacroix S, Boutin A, Moore L, et al., Hysterosalpingosonography for diagnosing tubal occlusion in subfertile women: a systematic review with meta-analysis. Hum Reprod 2014; 29:953-963.

7. Emanuel $\mathrm{MH}$ and $\mathrm{N}$ Exalto. Hysterosalpingo-foam sonography (HyFoSy): a new technique to visualize tubal patency. Ultrasound Obstet Gynecol 2011; 37:498-499.

8. Piccioni MG, Riganelli L, Filippi V, et al. Sonohysterosalpingography: Comparison of foam and saline solution. J Clin Ultrasound 2017; 45:67-71.

9. Van Schoubroeck D, Van den Bosch T, Ameye L, Boes AS, D'Hooghe T, Timmerman D. Pain during Fallopian-tube patency testing by hysterosalpingo-foam sonography. Ultrasound Obstet Gynecol 2015; 45:346-350.

10. Tanaka K, Chua J, Cincotta R, Ballard EL, Duncombe G. Hysterosalpingo-foam sonography (HyFoSy): Tolerability, safety and the occurrence of pregnancy post-procedure. Aust $\mathrm{N} \mathrm{Z} \mathrm{J}$ Obstet Gynaecol 2018; 58:114-118.

11. Bosteels J, Weyers S, Puttemans P, et al., The effectiveness of hysteroscopy in improving pregnancy rates in subfertile women without other gynaecological symptoms: a systematic review. Hum Reprod Update 2010; 16:1-11.

12. Fatemi HM, Kasius JC, Timmermans A, et al., Prevalence of unsuspected uterine cavity abnormalities diagnosed by office hysteroscopy prior to in vitro fertilization. Hum Reprod 2010; 25:1959-1965.

13. Emanuel $\mathrm{MH}$, van Vliet $\mathrm{M}$, Weber $\mathrm{M}$, Exalto $\mathrm{N}$. First experiences with hysterosalpingo-foam sonography (HyFoSy) for office tubal patency testing. Hum Reprod 2012; 27:114-117.

14. El-Toukhy $\mathrm{T}$, Campo $\mathrm{R}$, Khalaf $\mathrm{Y}$, et al., Hysteroscopy in recurrent in-vitro fertilisation failure (TROPHY): a multicentre, randomised controlled trial. Lancet 2016; 387:2614-2621.

15. Smit JG, Kasius JC, Eijkemans MJC, et al., Hysteroscopy before invitro fertilisation (in-SIGHT): a multicentre, randomised controlled trial. Lancet 2016; 387:2622-2629.

16. Cicinelli $E$, Matteo $M$, Tinelli $R$, et al. Prevalence of chronic endometritis in repeated unex-plained implantation failure and the IVF success rate after antibiotic therapy. Hum Reprod 2015;30:323-330.

17. Cao H, You D, Yuan M, Xi M. Hysteroscopy after repeated implantation failure of assisted reproductive technology: A metaanalysis. J Obstet Gynaecol Res 2018; 44:365-373. 
18. Parry JP, Riche D, Rushing J, Linton B, Butler V, Lindheim SR. Performing the Parryscope technique gently for office tuba patency assessment. Fertil Steril 2017; 108:718.

19. Karande CV, Pratt ED, Gleicher N. The assessment of tubal functional status by tubal perfusion pressure measurements. Hum Reprod Update 1996; 2:429-433.

20. Carta G, Palermo P, Pasquale C, et al. Office hysteroscopic-guided selective tubal chro-mopertubation: acceptability, feasibility and diagnostic accuracy of this new diagnostic non-invasive technique in infertile women. Hum Fertil (Camb) 2018; 21:106-111.

21. Habibaj J, Kosova H, Bilali S, Bilali V, Qama D. Comparison between transvaginal sonog-raphy after diagnostic hysteroscopy and laparoscopic chromopertubation for the assessment of tubal patency in infertile women. J Clin Ultrasound 2012; 40:68-73.
22. Gordts S, Campo R, Puttemans $P$, et al. Investigation of the infertile couple: a one-stop out-patient endoscopy-based approach. Hum Reprod 2002; 17:1684-1687.

23. Magos A, Al-Khouri A, Scott $P$, et al. One stop fertility clinic. J Obstet Gynaecol 2005; 25:153-159.

24. Hrehorcak M, Nargund G. "One-Stop" fertility assessment using advanced ultrasound tech-nology. Facts Views Vis Obgyn 2011; 3:8-12. 